ECS Transactions, 68 (1) 1121-1128 (2015)

10.1149/06801.1121ecst (CThe Electrochemical Society

\title{
In situ Tailored Nickel Nano-catalyst Layer for Internal Reforming Hydrocarbon Fueled SOFCs
}

\author{
Jae-ha Myung, Dragos Neagu, Mark Tham and John T.S. Irvine \\ School of Chemistry, University of St Andrews, St Andrews, Fife, KY16 9ST, UK
}

\begin{abstract}
Conventional $\mathrm{Ni}$ cermet anodes suffer from carbon deposition when they are directly used with hydrocarbon fuels due to the negative effects of pyrolysis and Boudouard reactions. In this work, the use of a non-stoichiometric perovskite, $\mathrm{La}_{0.8} \mathrm{Ce}_{0.1} \mathrm{Ni}_{0.4} \mathrm{Ti}_{0.6} \mathrm{O}_{3}$, as a reforming layer in reducing atmospheres led to the surface being highly populated with homogeneously exsolved $\mathrm{Ni}$ nano particles. This catalyst layer was applied to Ni-GDC anode supported and ScSZ electrolyte supported cells to prevent carbon deposition and to stabilize operation with dry methane. The catalyst layer showed both excellent attachment to the Ni-GDC anode and resistance to carbon deposition. The performance of the $\mathrm{Ni}-\mathrm{GDC}$ anode-supported cells with the catalyst layer was about $1.1 \mathrm{~W} / \mathrm{cm}^{2}$ in hydrogen fuel which is similar to that seen without the use of a catalyst layer. For the ScSZ electrolyte supported cells, the catalyst layer improved the power density and stability when in operation with dry methane.
\end{abstract}

\section{Introduction}

Solid oxide fuel cells (SOFCs) are one of the most promising power generation systems because they are highly efficient, pollution-free and are able to directly convert the chemical energy into electrical energy (1-3). The state-of-the art commercial SOFCs systems generally use the hydrogen produced from hydrocarbon fuels by an external reformer. SOFCs have a strong advantage of direct utilization of hydrocarbon fuel without an external reformer. However, the carbon deposition occurs on the most widely used Ni cermet anodes which leads to deactivation and fracture of the cell or stack when under severe operating conditions $(4,5)$. Nevertheless, many researchers continue to study SOFCs for the direct utilization of hydrocarbon fuels due to the significant benefits they offers. These benefits include; it's abundant supply, low-cost and its compatibility with a current and well-developed gas distribution infrastructure $(6,7)$.

The alternative anodes for $\mathrm{Ni}$ cermet with a reliable metal such as $\mathrm{Cu}$-based metals or oxides have recently been investigated to prevent carbon coking. Perovskite-structured anode materials such as $\mathrm{La}_{1-\mathrm{x}} \mathrm{Sr}_{\mathrm{x}} \mathrm{Cr}_{0.5} \mathrm{Mn}_{0.5} \mathrm{O}_{3}$ (LSCM), $\mathrm{Sr}_{2} \mathrm{MgMoO}_{6-\delta}$, and La substituted $\mathrm{SrTiO}_{3}$ demonstrated good tolerance towards carbon coking at high current load conditions where sufficient oxygen ions were provided. It also showed, a comparable performance using hydrogen and a high resistance to carbon deposition when using hydrocarbon fuels (8-10). A $\mathrm{Ce}_{0.6} \mathrm{Mn}_{0.3} \mathrm{Fe}_{0.1} \mathrm{O}_{2}-\mathrm{La}_{0.6} \mathrm{Sr}_{0.4} \mathrm{Fe}_{0.9} \mathrm{Mn}_{0.1} \mathrm{O}_{3}$ anode have been reported to obtain over $1 \mathrm{~W} / \mathrm{cm}^{2}$ with propane and butane fuels because of their high catalytic activity in relation to direct hydrocarbon oxidation (11). However, when 
methane is supplied to these anodes, the oxide anode showed a lower power density than that of the conventional Ni-based anode due to insufficient electrical conductivity and catalytic activity with respect to methane. The modified oxides are emerging up by infiltration of various catalysts such as $\mathrm{Ni}, \mathrm{Pd}$, and $\mathrm{Rh}$ to enhance their activity of hydrocarbon fuels $(12,13)$. However, many problems still remain unsolved such as; carbon deposition, poor stability by metal coarsening and poor uniformity. Recently, insitu exsolution of metal particles from A-site deficient oxides has attracted attention as a potential solution to these problems. The characteristics such as; population, size, and composition of exsolved nano-particles can be easily controlled $(14,15)$. Also, as the exsolved Ni particles are pinned to its surface, it can prevent their agglomeration and carbon-wire growth. However, this oxide has very low electrical conductivity in comparison to $\mathrm{Ni}$ and other metal, the additional work are still required for applying in practical SOFCs by optimization of their composition and cell configuration.

Thus, in this study, we applied the A-site deficient perovskite (LCNT, $\mathrm{La}_{0.8} \mathrm{Ce}_{0.1} \mathrm{Ni}_{0.4} \mathrm{Ti}_{0.6} \mathrm{O}_{3}$ ) as a catalyst layer on $\mathrm{Ni}$-cermet anode; this cell configuration can compensate for the low electrical conductivity of oxide anode and carbon deposition of $\mathrm{Ni}$ cermet anode. Finally, the LCNT/Ni-ScSZ/ScSZ/LSM-ScSZ electrolyte supported cells showed much improved durability and power density without any degradation from carbon deposition when using methane fuel at $800{ }^{\circ} \mathrm{C}$. Furthermore, the LCNT/NiGDC/GDC/LSCF-GDC anode supported cell also showed $1.1 \mathrm{~W} / \mathrm{cm}^{2}$ of maximum power density as high as that of non-catalyst layered Ni-GDC cell at $650^{\circ} \mathrm{C}$ with hydrogen.

\section{Experimental}

Synthesis of $\mathrm{La}_{0.8} \underline{\mathrm{Ce}_{0.1}} \underline{\mathrm{Ni}_{0.4}} \underline{\mathrm{Ti}_{0.6}} \underline{\mathrm{O}_{3}}$

For the preparation of $\mathrm{La}_{0.8} \mathrm{Ce}_{0.1} \mathrm{Ni}_{0.4} \mathrm{Ti}_{0.6} \mathrm{O}_{3}$ by solid state synthesis, precursors including oxides $\left(\mathrm{La}_{2} \mathrm{O}_{3}\right.$, TiO 2 ), or nitrates $\left(\mathrm{Ce}\left(\mathrm{NO}_{3}\right)_{3} \cdot 6 \mathrm{H}_{2} \mathrm{O}, \mathrm{Ni}\left(\mathrm{NO}_{3}\right)_{2} \cdot 6 \mathrm{H}_{2} \mathrm{O}\right)$ were used in the proper stoichiometric ratios. The oxides and carbonates were dried at different temperatures depending on the nature of the precursor and weighed while hot (300$800^{\circ} \mathrm{C}$ ). All the precursors were quantitatively gathered into a beaker and mixed with acetone and Hypermer KD-1 dispersant. After breaking of agglomerated powder by ultrasonication, the powder was dried in an oven. Then, the contents of the beaker was moved into a crucible and calcined at $1000{ }^{\circ} \mathrm{C}$ for $12 \mathrm{~h}$ in order to decompose the carbonates, water and start the nucleation of the perovskite phase. After calcination, the powder was milled for $1.5 \mathrm{~h}$ in a planetary ball mill at $200 \mathrm{rpm}$ again, and pressed into dense pellets and fired for $12 \mathrm{~h}$ at $1450{ }^{\circ} \mathrm{C}$. The sintered pellets were crushed and ballmilled for $1 \mathrm{~h}$ at $1100 \mathrm{rpm}$.

\section{$\underline{\text { Fabrication of Single Cells }}$}

The electrolyte supported and anode supported single cells were employed to measure their electrochemical activity with hydrogen and methane fuels. The ScSZ powder was pressed into pellets and fired in air at $1500^{\circ} \mathrm{C}$ for another $12 \mathrm{~h}$ to obtain a dense support. The screen printing inks were prepared by using planetary ball milling in LSM-ScSZ/NiO-ScSZ and $\alpha$-terpineol with 10 wt\% of Hypermer KD1 dispersant (Uniqema). After this step, the slurry was added to an ink vehicle, consisting of $15 \mathrm{wt} \%$ 
PVB (polyvinyl butyral, Butvar, Sigma-Aldrich) in $\alpha$-terpineol and mixed again. The LSM-ScSZ and NiO-ScSZ inks were screen-printed onto each side of a dense ScSZ support $(300 \mu \mathrm{m})$ with thickness of $30 \mu \mathrm{m}$ and fired at $1200^{\circ} \mathrm{C}$ for $3 \mathrm{~h}$. Then LCNT catalyst layer screen printed on $\mathrm{NiO}-\mathrm{ScSZ}$ anode and fired at $1100^{\circ} \mathrm{C}$ for $3 \mathrm{~h}$. In these button cells, both anode and cathode had a surface area of $0.5 \mathrm{~cm}^{2}$. Anode supported cells consisting of Ni-GDC/GDC/LSCF-GDC were fabricated for electrochemical characterisation. The Ni-GDC ( $10 \mathrm{wt} \%$ of carbon black) anode supports were fabricated by a uni-axial pressing method and burn-out at $1150^{\circ} \mathrm{C}$ for $3 \mathrm{~h}$. GDC electrolyte was deposited by dip-coating method and sintering at $1350^{\circ} \mathrm{C}$ for $3 \mathrm{~h}$. After LSCT layer formed on Ni-GDC, the LSCFGDC cathodes (LSCF:GDC $=50: 50 \mathrm{wt} \%$ ) screen printed and sintered at $1000^{\circ} \mathrm{C}$ for $2 \mathrm{~h}$.

\section{$\underline{\text { SOFC Cell Test }}$}

The performances of the electrolyte supported cells were analyzed at $800^{\circ} \mathrm{C}$ in $\mathrm{H}_{2}$ $\left(50 \mathrm{ccmin}^{-1}\right.$ at standard ambient temperature and pressure) or dry methane $\left(50 \mathrm{ccmin}^{-1}\right.$ at standard ambient temperature and pressure) without any balanced gas at the anode and air (500 $\mathrm{ccmin}^{-1}$ at standard ambient temperature and pressure) at the cathode. The anode supported cells were evaluated at $650^{\circ} \mathrm{C}$ in $\mathrm{H}_{2}$. The I-V curve, durability and impedance data were measured using between $10^{5} \mathrm{~Hz}$ and $0.1 \mathrm{~Hz}$ were recorded using an IM6 and ZENNIUM workstation (Zahner-Elektrik GmbH \& Co.KG, Germany).

\section{Results and Discussion}

$\mathrm{Ni}$ on the anode enables methane gas to directly reform to syngas such as hydrogen, carbon monoxide and carbon dioxide. The syngas further undergoes a electrochemical reaction with oxygen ions which are transported from the cathode to three phase boundaries (TPBs) of anode through the electrolyte under load conditions.

In an ideal reaction (equation 1), direct electrochemical oxidation of methane without its chemical cracking, methane directly can be oxidized by lattice oxygen ions from the mixed conductor like as doped ceria oxide. However, it is required to carefully control the current flow and gas flow rate to minimize the carbon deposition. The ideal reaction exists within the three phase boundary at the inner anode, not in the outer anode where oxygen ions cannot reach.

$$
\mathrm{CH}_{4}+4 \mathrm{O}^{2-} \rightarrow \mathrm{CO}_{2}+2 \mathrm{H}_{2} \mathrm{O}+8 \mathrm{e}^{-}
$$

In the outer of $\mathrm{Ni}$ anode support, the pyrolysis reaction (equation 2) mainly occurs and suffers carbon deposition due to lack of oxygen ions.

$$
\mathrm{CH}_{4} \rightarrow \mathrm{C}+2 \mathrm{H}_{2}
$$

With the Ni exsoluted-catalyst layer for reforming of methane, the anode support can be protected from carbon deposition. Carbon growth and deposition over Ni has been extensively researched, deposition of a carbon source onto the metal surface, dissolution of the carbon into the bulk of the metal and finally precipitation of carbon as a fiber at the metal particle. But in this research, the exsoluted Ni particles pinned on the backbone oxide prevents the mechanism of carbon growth. Also, through this layer, it produces more hydrogen which is less molecular weight and faster reaction kinetic than of methane. 
As shown in Figure 1(a), $\mathrm{CO}$ and $\mathrm{H}_{2}$ are reformed at the catalyst layer for electrochemical reaction with oxygen ions at TPBs as equation 2 and 3.

$$
\begin{aligned}
& \mathrm{H}_{2}+\mathrm{O}^{2-} \rightarrow \mathrm{H}_{2} \mathrm{O}+2 \mathrm{e}^{-} \\
& \mathrm{CO}+\mathrm{O}^{2-} \rightarrow \mathrm{CO}_{2}+2 \mathrm{e}^{-}
\end{aligned}
$$

(a)

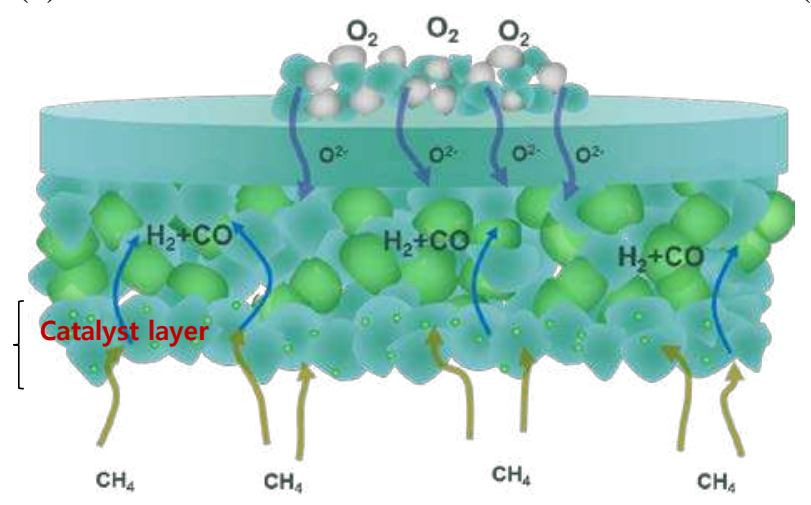

(b)

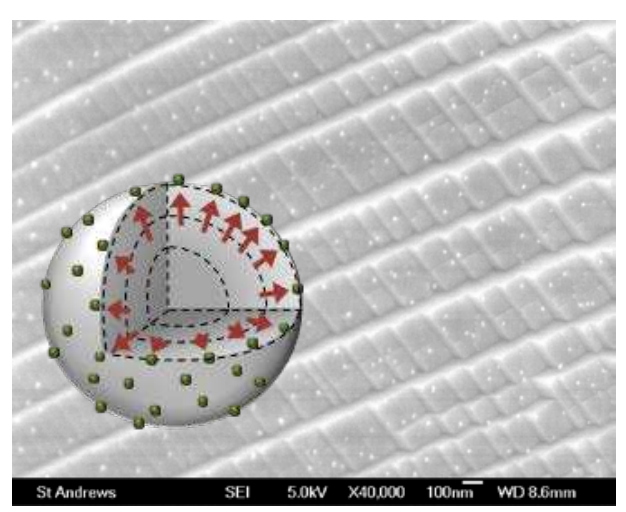

Figure 1. Schematic of (a) catalyst-layered anode supported cells and (b) the $\mathrm{Ni}$ exsolution of LCNT with SEM image.

Figure 1(b) shows the Ni exsolution of LCNT bulk sample after a reduction in $\mathrm{H}_{2}$ at $900^{\circ} \mathrm{C} .10 \sim 20 \mathrm{~nm}$ sized particles are homogenously distributed with high population. The pinned particles have strong advantages such as non-agglomeration, carbon resistance and high surface area. But it has a low electrical conductivity, possibly can lead to increase the Ohmic resistance without a careful preparation of current collection.

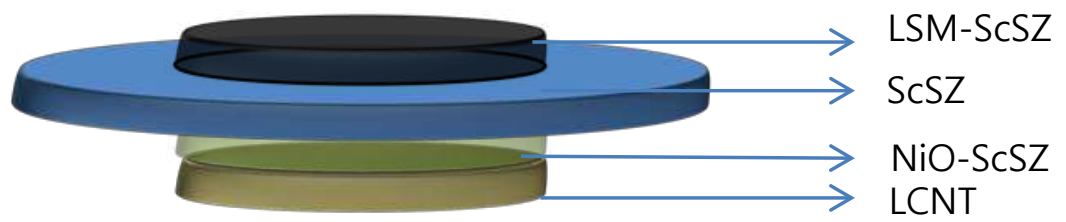

Figure 2. Schematic of catalyst-layered electrolyte supported cell.

The single cell was prepared by using the cell consisting of LCNT catalyst layer $(15 \mu \mathrm{m}) / \mathrm{NiO}-\mathrm{ScSZ}$ anode $(15 \mu \mathrm{m}) / \mathrm{ScSZ}$ electrolyte support (300 $\mu \mathrm{m}) / \mathrm{LSM}-\mathrm{ScSZ}(15 \mu \mathrm{m})$ as shown in Figure 2. The ScSZ electrolyte supported single cells were evaluated using pure $\mathrm{H}_{2}$ and $\mathrm{CH}_{4}$ as fuel, air as oxidant respectively, at $800^{\circ} \mathrm{C}$. The I-V curves and impedance spectra in $\mathrm{H}_{2}$ at $800^{\circ} \mathrm{C}$ are displayed in Figure 3. In order to further study the electrode polarization (Rp) during cell performance, the impedance measurement was conducted under open current voltage (O.C.V) condition. The impedance spectra consists of at least three semicircles and intercept with the real axis: high frequency arc $\left(\mathrm{Q}_{H} \mathrm{R}_{\mathrm{H}}\right)$, mid frequency arc $\left(\mathrm{Q}_{M} \mathrm{R}_{\mathrm{M}}\right)$ and low frequency arc $\left(\mathrm{Q}_{\mathrm{L}} \mathrm{R}_{\mathrm{L}}\right)$ as non-ohmic resistance $\left(\mathrm{Rp}=\mathrm{R}_{\mathrm{H}}+\mathrm{R}_{\mathrm{M}}+\mathrm{R}_{\mathrm{L}}\right)$ and ohmic resistance $(\mathrm{Rs})$, suggesting that the high and mid frequency resistance could be assigned to surface activation, charge transfer process while the lower frequency resistance with gas diffusion and conversion reactions. The high frequency interception (Rs) is Ohmic resistance which is mainly caused from the electrolyte. The 
maximum power density with catalyst layer shows $0.22 \mathrm{~W} / \mathrm{cm}^{2}$, higher than $0.19 \mathrm{~W} / \mathrm{cm}^{2}$ of non-catalyst layered cell at $800{ }^{\circ} \mathrm{C}$. Two or three semicircles were roughly observed on impedance fitting plot and considering response frequency.

(a)

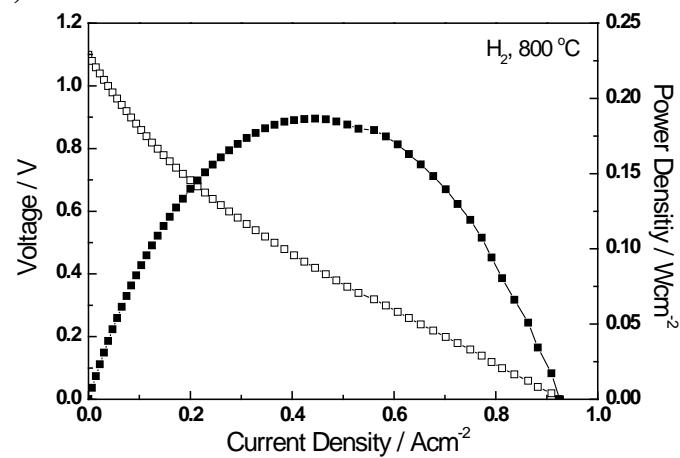

(c)

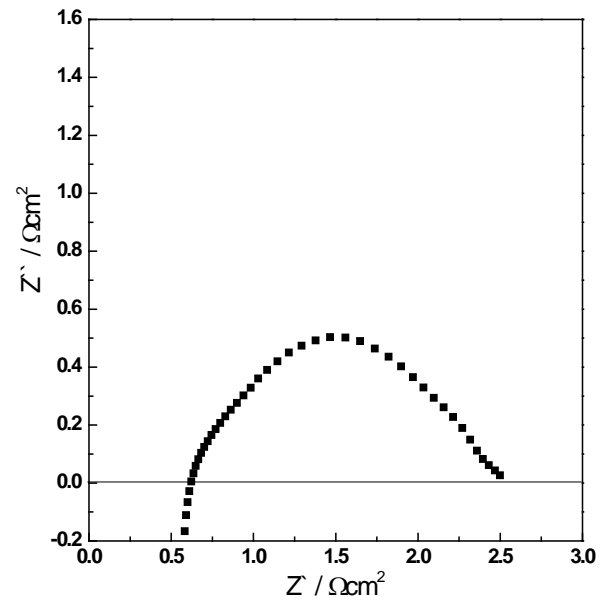

(b)

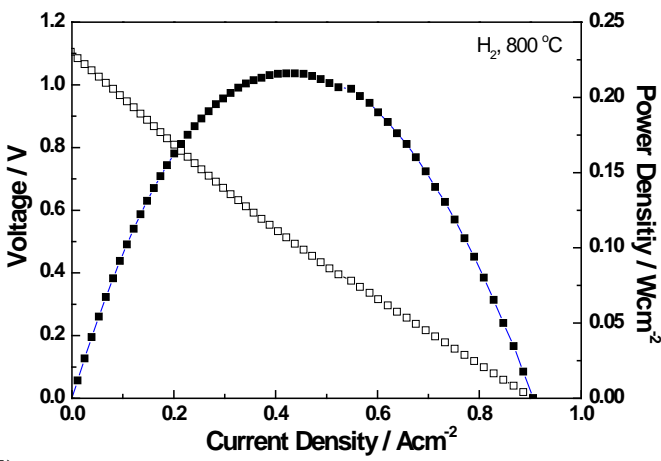

(d)

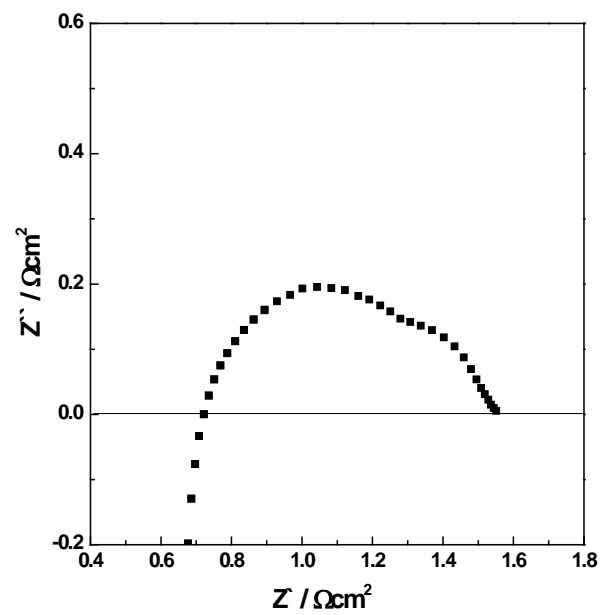

Figure 3. I-V curves and impedance spectra in $\mathrm{H}_{2}$ at $800^{\circ} \mathrm{C}$ for $\mathrm{ScSZ}$ electrolyte supported cells $(a, c)$ without and $(b, d)$ with LCNT catalyst layer.

Clearly the high frequency interception (Rs) has barely changed, though a slight increase is seen from $0.62 \Omega \mathrm{cm}^{2}$ to $0.72 \Omega \mathrm{cm}^{2}$ because of the slightly different thickness of electrolyte support or low conductivity of catalyst layer. Total electrode polarization reduced from $1.9 \Omega \mathrm{cm}^{2}$ to $0.78 \Omega \mathrm{cm}^{2}$. The high and mid frequencies were reduced considerably in comparison with Figure $3 \mathrm{c}$ and $3 \mathrm{~d}$. It indicates that surface activation for hydrogen and charge transfer process improved, but there is no big difference at low frequency because it is not a reforming reaction.

The catalyst layer explicitly affects the stability and performance with methane at $800^{\circ} \mathrm{C}$ as shown in Figure 4. The O.C.V. and maximum power density of the catalyst layered SOFC showed a value of $0.915 \mathrm{~V}$ and $33 \mathrm{~mW} / \mathrm{cm}^{2}$. This is higher than that of $0.882 \mathrm{~V}$ and $22 \mathrm{~mW} / \mathrm{cm}^{2}$ for the non-catalyst layered SOFC. Although O.C.V. values of both cells have lower than theoretical value of $\approx 1.1 \mathrm{~V}$ due to the insufficient thickness of anode to fully react with methane and a slower kinetic in comparison with it of hydrogen, it is confirmed that the catalyst layer enhances O.C.V value and stability for methane. Rs and $\mathrm{Rp}$ value of catalyst layered SOFC in $\mathrm{CH}_{4}$ shows $1.04 \Omega \mathrm{cm}^{2}$ and $2.5 \Omega \mathrm{cm}^{2}$, which are reduced at entire frequencies in comparison of non-catalyst layered SOFC. The 
pyrolysis of methane (equation 2) is an endothermic dissociation reaction that the $\mathrm{C}-\mathrm{C}$ bond is weaker than the $\mathrm{C}-\mathrm{H}$ bond. It is possible to decrease the temperature in some local areas and lead to increase Rs value, $1.04 \Omega \mathrm{cm}^{2}$ with $\mathrm{CH}_{4}$ from $0.72 \Omega \mathrm{cm}^{2}$ with $\mathrm{H}_{2}$. In order to further analysis of the anodic polarization, impedance spectroscopy results are undergoing via a three electrode test. Although the thickness of the catalyst layer is not yet optimized for pyrolysis of methane, it demonstrated that the catalyst layer stabilizes SOFC operation in dry methane without carbon deposition.

(a)

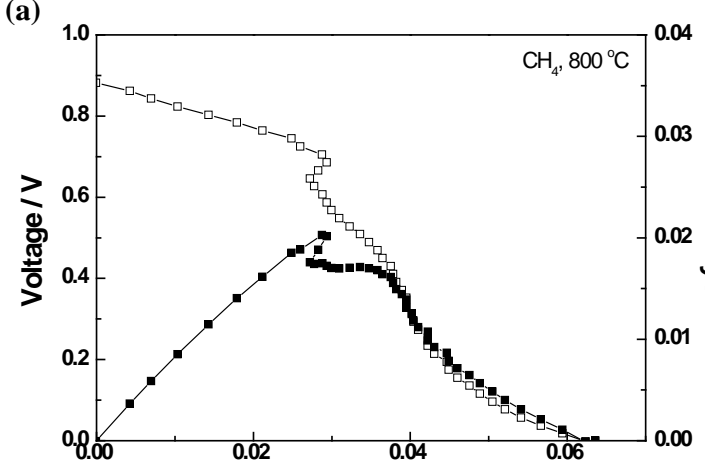

(c)

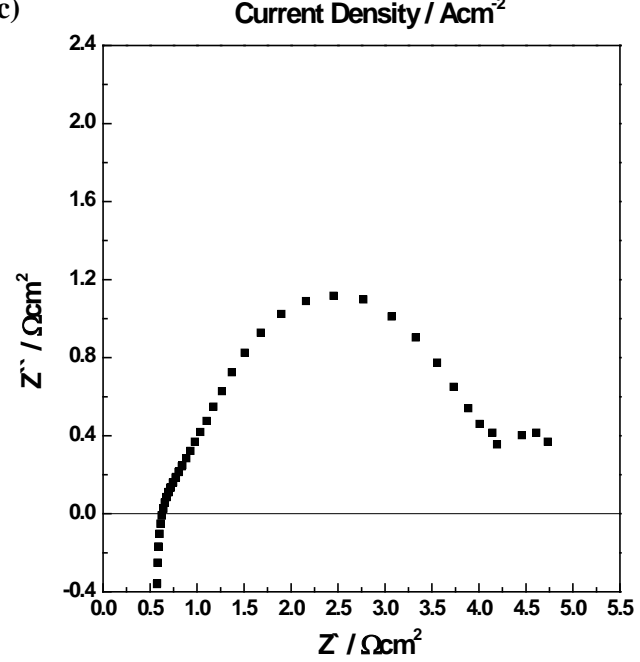

(b)

(d)
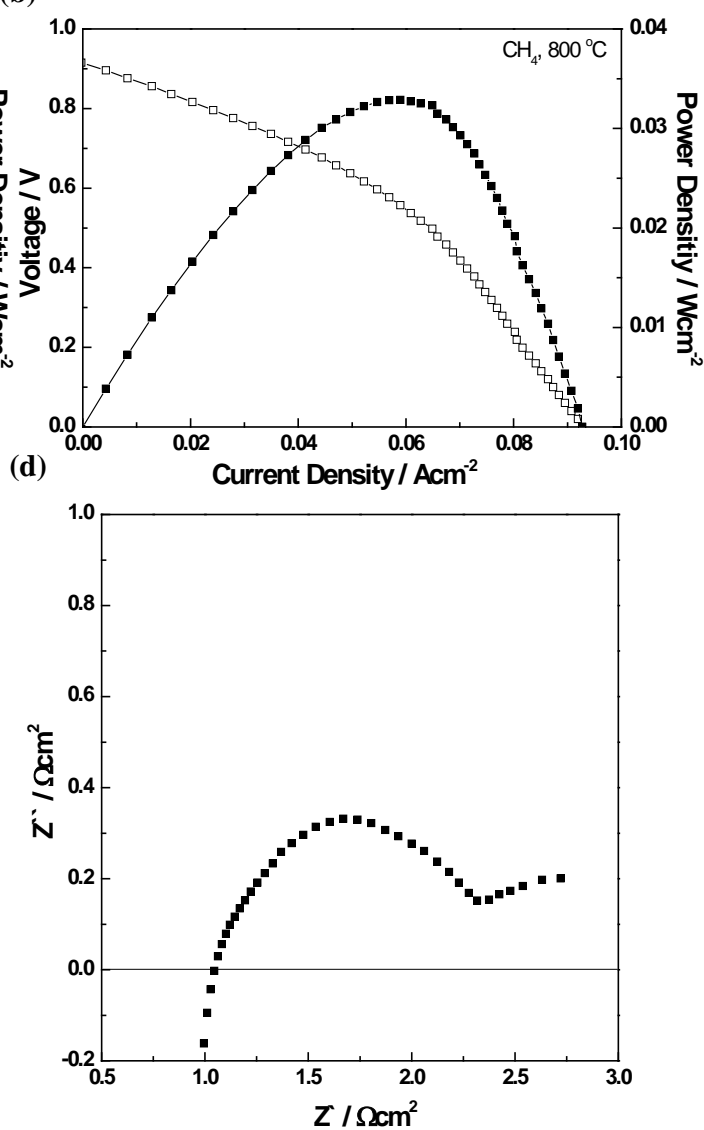

Figure 4. I-V curves and impedance spectra in $\mathrm{CH}_{4}$ at $800^{\circ} \mathrm{C}$ for $\mathrm{ScSZ}$ electrolyte supported cells $(\mathrm{a}, \mathrm{c})$ without and $(\mathrm{b}, \mathrm{d})$ with LCNT catalyst layer.

The catalyst layer was also applied on a Ni-GDC anode supported single cell to achieve a higher performance at lower temperature, $650^{\circ} \mathrm{C}$. The $\mathrm{I}-\mathrm{V}$ curves and impedance spectra are displayed in Figure 5. The maximum power density Rs and Rp values for catalyst-layered SOFC shows over $1.1 \mathrm{~W} / \mathrm{cm}^{2}$, and 0.07 and $0.1 \Omega \mathrm{cm}^{2}$, respectively, which is slightly higher than that of non-catalyst layered SOFC at $\mathrm{H}_{2}$. Figure 6 shows the microstructure of LCNT catalyst layer after a cell test in $\mathrm{H}_{2}$ at $650^{\circ} \mathrm{C}$.

The firing temperature for forming the layer in fabrication procedure needs to reduce for higher porosity to enable better gas diffusion, as well, the temperature and duration time of reduction require to increase for higher population of the exsoluted $\mathrm{Ni}$ particles. The performance of Ni-GDC anode supported single cells with LCNT catalyst layer is now analyzing in $\mathrm{CH}_{4}$ and presenting in the conference. 
(a)

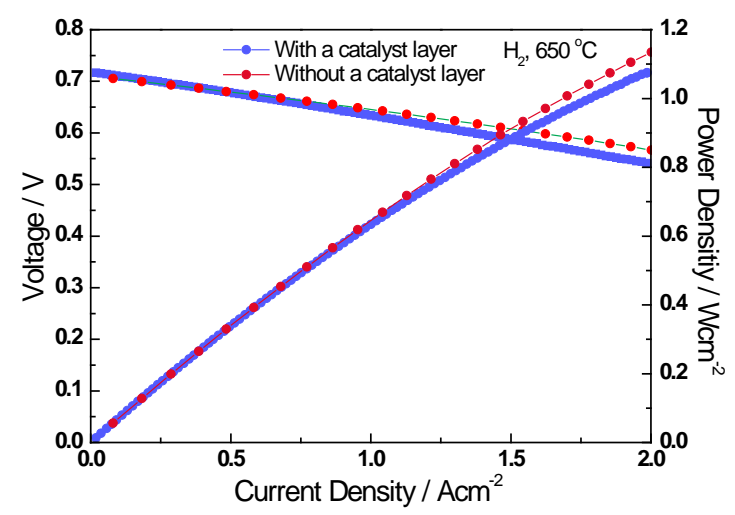

(b)

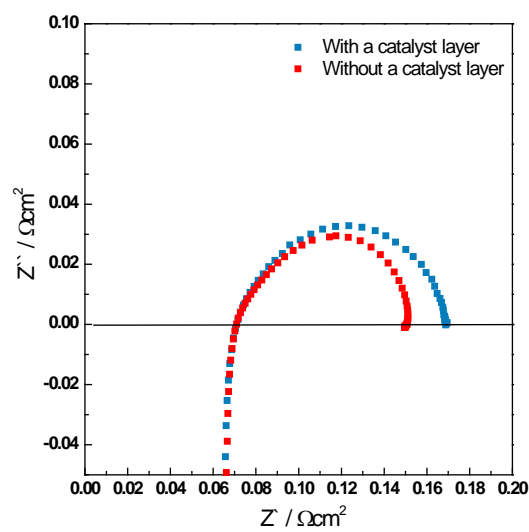

Figure 5. (a) $\mathrm{I}-\mathrm{V}$ curves and (b) impedance spectra in $\mathrm{H}_{2}$ at $650^{\circ} \mathrm{C}$ for Ni-GDC anode supported cells with/without LCNT catalyst layer.

(a)

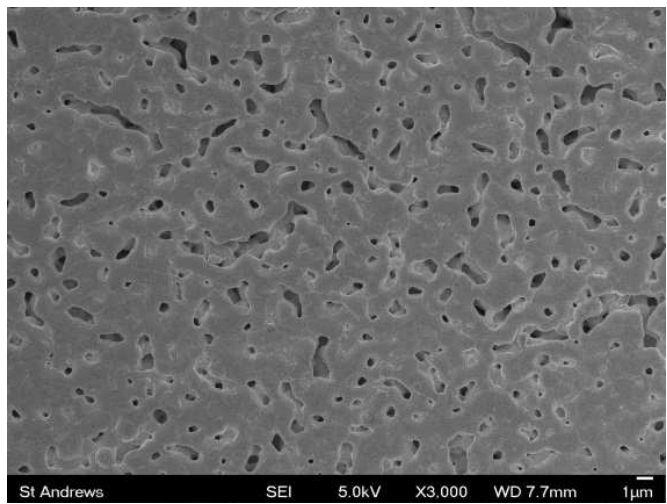

(b)

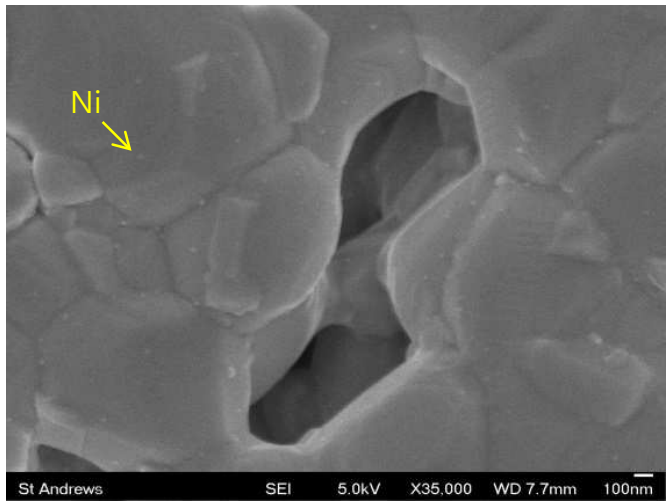

Figure 6. SEM images of LCNT catalyst layer with (a) $x 3,000$ and (b) $x 35,000$ magnifications.

\section{Conclusions}

Non-stoichiometric perovskite $\left(\mathrm{La}_{0.8} \mathrm{Ce}_{0.1} \mathrm{Ni}_{0.4} \mathrm{Ti}_{0.6} \mathrm{O}_{3}\right)$ material for a catalyst layer to direct reforming of methane was successfully prepared. The effects of this layer on electrochemical performance of SOFCs have been investigated. The electrochemical results from $\mathrm{ScSZ}$ electrolyte supported cell using $\mathrm{H}_{2}$ and $\mathrm{CH}_{4}$ as fuel and air as oxidant showed that LCNT can be successfully utilized as a catalyst layer to prevent the carbon deposition and reforming of $\mathrm{CH}_{4}$; a maximum power density of $\mathrm{ScSZ}$ electrolyte supported cells with LCNT showed $33 \mathrm{~mW} / \mathrm{cm}^{2}$ with $2.5 \Omega \mathrm{cm}^{2}$ of ASR at $800{ }^{\circ} \mathrm{C}$ with operating in $\mathrm{CH}_{4}$. Further, any performance degradation in $\mathrm{H}_{2}$ by the catalyst layer on $\mathrm{Ni}$ GDC anode supported cell could not be significantly observed.

\section{Acknowledgments}

The authors gratefully thank the Engineering and Physical Sciences Research Council (EPSRC) SuperGen Hydrogen Fuel Cells Challenges Flame SOFC Project (Grant No EP/K021036/1) for financial support. 


\section{References}

1. R. Bashyam and P. Zelenay, Nature, 443, 63-66 (2006).

2. E. D. Wachsman and K. T. Lee, Science, 334, 935 -939 (2011).

3. E. D. Wachsman, C. A. Marlowe and K. T. Lee, Energy Environ. Sci., 5, 54985509 (2012).

4. R. J. Gorte, H. Kim and J. M. Vohs, J. Power Sources, 106, 10-15 (2002).

5. S. McIntosh and R. J. Gorte, Chem. Rev., 104, 4845-4865(2004).

6. M. J. Taherzadeh and K. Karimi, Int. J. Mol. Sci. 9, 1621-1651 (2008).

7. C. Song, Catal. Today 115, 2-32 (2006).

8. S. Tao and J. T. S. Irvine, Nat. Mater., 2, 320-323 (2003).

9. Y. H. Huang, R. I. Dass, J. C. Denyszyn and J. B. Goodenough, J. Electrochem. Soc, 153(7), A1266-A1272 (2006).

10. D. Neagu and J. T. S. Irvine, Chem. Mater., 22, 5042-5053 (2010).

11. T. H. Shin, S. Ida and T. Ishihara, J. Am. Chem. Soc., 133, 19399-19407 (2011).

12. J. M. Vohs and R. J. Gorte, Adv. Mater., 21, 943-956 (2009).

13. G. Kim, S. Lee, J. Y. Shin, G. Corre, J. T. S. Irvine, J. M. Vohs and R. J. Gorte, Electrochem. Solid State Lett., 12(3), B48-B52 (2009).

14. D. Neagu, G. Tsekouras, D. N. Miller, H. Ménard and J. T. S. Irvine, Nat. Chem., 5, 916-923 (2013)

15. D. Neagu and J. T. S. Irvine, Chem. Mater., 23, 1607-1617 (2011). 